\title{
What is an Animal? A Philosophical Reflection on the Possibility of a Moral Relationship with Animals
}

\author{
HUB ZWART
}

Center for Ethics

Catholic University of Nijmegen

6500 HD Nijmegen, The Netherlands

\begin{abstract}
Contemporary ethical discourse on animals is influenced partly by a scientific and partly by an anthropomorphic understanding of them. Apparently, we have deprived ourselves of the possibility of a more profound acquaintance with them. In this contribution it is claimed that all ethical theories or statements regarding the moral significance of animals are grounded in an ontological assessment of the animal's way of being. In the course of history, several answers have been put forward to the question of what animals really and basically are. Three of them (namely the animal as a machine, an organism and a being that dwells in an - apparently - restricted world) are discussed. It is argued that the latter (Heideggerian) answer contains a valuable starting point for an ethical reflection on recent changes in the moral relationship between humans and animals.
\end{abstract}

KEYWORDS: Animal ethics, ontology and ethics, Heidegger on animals, anthropomorphism, biotechnology

\section{INTRODUCTION}

'Now, what I want is, Facts. Teach these boys and girls nothing but Facts. Facts alone are wanted in life. Plant nothing else, and root out everything else. You can only form the minds of reasoning animals upon Facts.' Those are the words of the horrible teacher Gradgrind in Dickens's novel Hard Times who, being informed that Sissy's father is a horsebreaker, demands that she give the definition of a horse. Although Sissy (due to her daily companionship with them) is intimately acquainted with horses, she is nevertheless startled by the question and unable to answer it. 'Girl number twenty unable to define a horse! Girl number twenty possessed of no facts, in reference to one of the commonest of animals!', Gradgrind exclaims, and passes the question over to a boy who perhaps never so much as touched a horse, but who produces the perfect answer right away: 'Quadruped. Graminivorous. Forty teeth, namely twenty-four grinders, four eye-teeth, and twelve incisive. Sheds coat in spring... [etc.]' (1974 p. 5). 


\section{HUB ZWART}

It goes without saying that 'girl number twenty', because of her silence, is Dickens's heroine. She knows too much about horses, about their way of beingin-the-world to force her image of them into a factual definition. That is, she refuses to become a 'reasoning animal', someone who defines the world in objective, factual terms. She seems to realise that such a language will not allow us to articulate what horses really are. The animal's way of being is obscured rather than brought to light by the restricted and impoverished language of facts and definitions. Rather than allowing us to understand them, it is bound to estrange us from them.

The comic nature of the scene resides in the fact that Gradgrind demands a certain speech genre (the objective, scientific language of facts and definitions) to be automatically applied to any object whatsoever (cf. Bergson, 1940/1969). Eventually, however, it is the human being, rather than the horse who finds himself impoverished by this ridiculous procedure. Indeed, in Dickens's novel, the definition of the horse is preceded by a definition of man as a 'reasonable animal'. In order to be able to perceive the world in factual terms, this is what we have to become, depriving ourselves of other possibilities of existence. While defining animals in strictly objective terms, we deprive ourselves of the possibility of a more genuine companionship with them. Gradgrind's definition of a horse is as comic as the famous definition of man as a featherless biped, attributed to Plato and mocked by Diogenes the Cynic, who once plucked a fowl and brought him into the lecture room with the words, 'Here is Plato's man'. As a result of this joke, 'having broad nails' was added to the definition (Diogenes Laertius 1925/1979, 6:40).

The reason for referring to this comic passage in Dickens's novel is, that it points to something which I consider of great importance. The apparent selfevidence of the scientific (objective, factual) understanding of the world has decreased our ability to discern what animals really are. Contemporary moral discourse on animals is influenced partly by a scientific (biological, ethological or ecological) understanding of them and partly by an anthropomorphic understanding of them (treating them as if their way of being-in-the-world is similar to that of humans). Apparently, we have estranged ourselves from the possibility of a more profound acquaintance with them, a more profound understanding of their being. In this contribution, therefore, I will put forward the contention that a convincing assessment of the moral status of animals can only be achieved if we refrain from allowing our image of them to be obscured either by a scientific or by an anthropomorphic stance. In other words, whenever the moral relationship between humans and animals is at stake, the question regarding the is (the animal's way of being-in-the-world) must always precede the question regarding the ought (why is it that animals ought to be treated carefully and respectfully?). In order to answer the question how animals should be treated by us, we must become aware of the extent to which contemporary discourse reveals our actual estrangement from them. All ethical theories or statements regarding the moral significance of animals are explicitly or implicitly grounded in an ontological assessment of the animal's way of being. Many of these assessments 
WHAT IS AN ANIMAL?

are in need of thorough reconsideration, or must be regarded as misguided and pernicious. Most notably, the fundamental difference between the way of being of animals and humans often tends to be obscured, either by an anthropomorphic understanding of animals (considering them as persons or partners), or by a physiomorphic understanding of humans (regarding them merely as a biological species - an understanding similar to the one mocked by Diogenes - so that our understanding of the animality of animals (as well as the humanity of humans) is obscured.

The term 'animal' is of course very general and refers to greatly divergent forms of life, triggering distinctive reflections and responses. Therefore, a restriction has to be made as to the scope of this article. In this contribution, whenever I use the term animals, I actually confine myself to mammals, evading or postponing a moral and/or ontological reflection on other forms of life.

Now, when discussing the moral significance of animals (in the sense of mammals), most of us will start from the moral conjecture that animal life cannot be regarded as purely instrumental, as a mere resource ready at hand to be used and spent in service of human well-being, or as something completely irrelevant to morality. Animals do seem to have a good of their own, something like 'intrinsic value'. Yet, as soon as we try to clarify what such notions really mean, we often seem to be extrapolating anthropomorphic ideas and categories, developed in the context of an ethical discourse on humans, into the realm of animal life. In doing so, we allow these concepts to lose their original significance, we obscure them and turn them into mere rhetorical phrases rather than conceptual tools. Again, it is only after we have seriously questioned the is, the animal's fundamental way of being-in-the-world, that a satisfactory discourse concerning the ought - our duties and obligations towards animals - is likely to emerge.

In the course of history, several answers have been put forward to the question of what animals really and basically are. In this contribution, I will discuss three of them, starting with the scholastic-Cartesian understanding of animals as machines (Part 2). Then I will proceed to Kant's understanding of animals as organisms (Part 3), and finally I will discuss the basic differencebetween animals and humans as articulated by Heidegger (Part 4). All three answers to the question what animals are contain a moral stance towards them, a moral assessment of animals. Eventually, I shall opt for a view rather congenial to Heidegger's, and I will explore the ethical impact of such a view in terms of the present debate (Part 5). I will be criticising both an anthropomorphistic understanding of animals and a physiologistic understanding of man (cf. Oudemans 1996) and will point to the urgency of a more convincing understanding of the animality of animals - and, by implication, of the humanity of man. ${ }^{1}$ Gradgrind's definition of a horse implied a certain view of man (man as a reasonable animal), and also the scholastic-Cartesian understanding of animals as a machine was intimately connected with a particular understanding of human existence. Likewise, a more convincing understanding of animals will enhance a more profound understanding of what we are ourselves. 


\section{HUB ZWART}

\section{THE ANIMAL AS A MACHINE}

One philosophical answer to the question of what animals really are has been remarkably influential, namely the idea that an animal is basically identical to a machine. According to Nietzsche, Descartes was the first who, with a remarkable audacity, dared to think of animals this way. Ever since, physiologists have been trying to verify this proposition. ${ }^{2}$

While dwelling in the Netherlands, Descartes (besides attending anatomical lessons involving human corpses) was very much engaged in the practice of dissecting and analysing bodily parts of animals. It is said that he was accustomed to pay daily visits to the slaughterhouses in order to collect interesting material to be anatomised at home (Lindeboom 1979). The result of his diligence was the elaboration of an ontology containing the basic contention that animals (as well as human bodies) are basically machines. They are not like machines in the sense that the machine merely serves as a metaphor. To Descartes, the animal really is a machine, and the way of being of an animal is basically similar to that of a machine, an instrument manufactured by man. This implies that the phenomena of animal (as well as bodily) life can be understood in strictly mechanistic terms.

Nietzsche is mistaken, however, in presenting Descartes' proposition as an unprecedented modern view. To a considerable extent, Descartes' ontological ideas still rely on the very mode of thought he pretended to despise so much scholasticism. In fact, the idea that animals are basically similar to human artefacts, can be encountered in the principal work of the most outstanding representative of scholasticism - the Summa Theologica of Thomas Aquinas. In Pars la 2 ae of this summa, the second article of Quaestio XIII is devoted to the issue whether animals are endowed with the faculty of free choice, that is: whether they display resoluteness and goal-oriented behaviour. At first glance, Thomas argues, this seems to be the case, for it looks as if they intend to realise certain goals in an conscious and active manner. Moreover, they do seem to have the ability to choose. A cow, for example, will devour certain kinds of herbs, while completely avoiding others. At times, moreover, animals are said to display remarkable signs of sagacity. A dog tracking a deer seems to choose between different options in a syllogistic, calculating manner. Yet, Thomas maintains that eventually we must recognise that animal behaviour is completely determined. They are by nature equipped with a rather limited set of options, and in a given situation it is rather predictable what they will choose. The facultyof free choice is denied to them. Although being sensitive, the objects of their sensitivity are predetermined by nature, rather than purposively and selfconsciously chosen in view of some good. Although they seem to prefer some things above others (for example some herbs above others), these choices are predetermined by nature. The movements of animals, Thomas argues, can be compared to those of arrows. Although one might have the impression that it is the arrow itself that tries to strike the target, it is of course the archer who is 
WHAT IS AN ANIMAL?

responsible for it and who makes the arrow take its course. The movements of animals are like those of horologia - clockworks - or other artefacts, with the difference that whereas horologia are human artefacts, manufactured by man, natural things are divine artefacts. Although animals seem to move on their own accord, and even seem to display a certain amount of intelligence, their are in fact pre-ordained to act the way they do. The wisdom and sagacity apparently displayed by animals themselves, is actually the wisdom and sagacity of Him who manufactured them and brought them into existence.

From the end of the eighteenth century onwards, philosophy tried to liberate itself form this mechanistic conception of animals, prepared by scholasticism and elaborated in the seventeenth and eighteenth century. In the present century, the mechanistic view was severely criticised by philosophers like Heidegger and Merleau-Ponty, although their contemporary Lacan still endorsed it and even exaggerated it by considered machines as being more free than animals are (1978, p. 44). Protagonists of mechanicism like Descartes and La Mettrie, he argues, were still thinking very much in scholastic terms. What Descartes tried to discover inside animal and human bodies was the clockwork, the horologia (p. 93/94). Yet, whereas animals have hardly changed since then, machines have greatly improved. Therefore, compared to our machines, the animal must be regarded as a jammed machine, since its parameters are fixed and determined by its innate equipment as well as by its environment. In terms of freedom and intelligence, our machines are more similar to human beings than to animals, and to compare an animal to a machine must nowadays be regarded as a form of praise rather than degradation.

The view that an animal is basically a machine (referred to as 'mechanicism') will hardly encourage the development of a moral stance towards animals. Rather, it is an is which silences the ought, an answer to the question of what animals are which instrumentalises them and subordinates them to human objectives, disregarding them as objects of moral concern. In order to criticise such an anthropocentric stance, however, we must first criticise the instrumentalisation of animals, the ontological understanding in which the moral assessment is grounded. Therefore, Kant's complicated effort to understand animal life as an organic rather than as a mechanistic phenomenon must now be taken into consideration.

\section{THE ANIMAL AS AN ORGANISM}

Kant's philosophical point of departure is the distinction between the phenomenal realm (the empirical, factual realm of causality, explored by the sciences) and the noumenal realm (the realm of freedom and reason). Whereas animals will never enter the noumenal realm (it is a possibility which is fundamentally denied to them), humans dwell in both. Man is both an empirical phenomenon (the object of psychology and biology) and a moral subject. This implies that, 


\section{HUB ZWART}

whereas animal behaviour is completely determined by nature (and must be regarded as consisting of nothing but fixed behavioural patterns triggered by stimuli from the environment), humans are self-conscious beings who can be expected to act in accordance with reasonable standards and goals.

With regard to the ontological status of animals, Kant initially seems to take a mechanistic position, one rather similar to that of Descartes and the scholasticmechanistic tradition. Moreover, he clearly states what the instrumentalisation of animals implies from a moral point of view. Instead of being an end in itself, he argues, an animal, lacking self-consciousness, must be regarded as a means which allows us to realise our reasonable ends. Therefore, we do not have any immediate obligations towards them (Kant 1990). Rather, our duties towards animals are derivative of our obligations towards man, the true object of our moral concern. ${ }^{3}$ We should refrain from cruelty towards animals because it is likely to enhance cruelty towards humans and because we are really degrading ourselves by displaying such behaviour. Nevertheless, although cruel in itself, vivisection in the context of an experiment is admissible because animals must be regarded as instruments of man. ${ }^{4}$ And rather than subjecting humans to medical experiments, we should make use of viler bodies - Fiat experimentum in corpore vili (1959). Apparently, the moral instrumentalisation of animals advocated by Kant is closely connected with the ontological one, also supported by him. Yet, already in his Critique of Judgement, but perhaps even more so in his Opus Postumum, a different understanding of animals emerges. An animal, Kant now argues, is not a machine, it is an organism. What does this mean?

Although Kant initially seems to be in agreement with a mechanistic conception of animal life, he eventually comes to reject it, arguing that animals are conscious beings, that their behaviour is guided by 'representations' of the environment and that this distinguishes them from mere machines, which act completely automatically (Naragon, 1990). This forces him, however, to take a rather complicated and ambiguous position. Naragon summarises Kant's ambiguity regarding animals (or 'brutes') in the following manner: 'Brutes can be thought of as machines and according to the universal causality of the phenomenological world they are machines, but they cannot be comprehended or understood as machines' (p. 22). This means that, although up to a certain point animals can be regarded as determined in a mechanical way, this is not the whole story and the machine-model does not allow us to understand the animal as an organism. Rather, it leaves us with a reduced and impoverished picture of animal life. In order for a science of animal life (biology) to be possible, we have to reflect on what being an organism means. That is, we have to acknowledge the fundamental difference between organisms and machines, as well as between biology and physics.

Physics necessarily starts from the supposition that natural phenomena can be described solely in mechanistic terms, as if the were completely determined by causality. This does not imply, however, that natural entities really are machines. In fact, a mechanistic point of view does not allow us to consider the 
WHAT IS AN ANIMAL?

apparent purposiveness or goal-orientedness which can be discerned in nature. In the case of machines, the goal or purpose is external to the thing itself. The machine itself does not have a goal but is put to use by man in order to realise a particular objective. In the case of animals, however, we discern a purposiveness which is already there, intrinsic to the organism itself. In order for a science of biology to be possible, we must recognise that animal life already seems to be directed at achieving certain goals. Because of this, we are bound to think of natural entities as if they are manufactured by a Divine Creator, out of a certain intention - we perceive them as if they were works of art in the sense of technè.

In short, apart from the mechanical or physical aspect we must also consider the technical or organic aspect of nature. In the first case, nature functions automatically, without purpose, and up to a certain point, all things in nature can be described in this manner (namely as mechanisms with no intrinsic purpose of their own). Yet, the organic or 'technical' aspect of nature must also be taken into consideration. It can be discerned if the apparent intrinsic purposiveness of nature - the technica naturalis - is acknowledged. Because of this technica naturalis, ancient and medieval philosophy concluded that nature really is manufactured or constituted by a Divine Creator, but according to Kant this conclusion has become problematic. The apparent purposiveness, he claims, is not constitutive for nature itself. Rather, it is the way nature is perceived by $u s$. We are the ones who perceive animals as if the are inherently oriented at realising certain goals, but we cannot conclude from this that the purpose or intention of a Divine Creator is behind it all. Should man be absent, nature would be a wasteland deprived of purpose. Although animals do not act automatically but are guided by representations, we cannot really say that their behaviour is goaloriented in the sense that they are able to develop intentions of their own. For although animals are conscious beings, only reasonable and self-conscious beings - that is, human beings - have the capacity to set and realise goal of their own - reasonable goals. Whereas the apparent goals of animals remain predetermined by the laws of nature, only humans allow their goals to be determined by the laws of freedom (that is, our sense of moral obligation). What does this imply when it comes to assessing the moral status of animals? Does Kant really succeed in transcending the scholastic-mechanistic instrumentalisation of them? Heidegger's answer to this is that he does not.

\section{THE ANIMAL'S WAY OF BEING-IN-THE-WORLD}

According to Descartes, the animal really is similar to a machine. Kant, as we have seen, claims that although an animal can be thought of as a machine, the machine-model does not allow us to acknowledge the organic aspect of animal life. Initially, Heidegger (1983) seems to side with Kant. Physics, he argues, presents us with an adequate but reduced picture of the world. Animals are living beings and physics does not enable us to understand what being a living being 


\section{HUB ZWART}

really means. Yet, Heidegger subsequently points out that Kant's position cannot be considered as satisfactory either. For although he acknowledges that an animal is more than a machine, the kantian understanding of nature remains thoroughly instrumentalistic. By defining the organic (as opposed to the physical) aspect of nature as 'technical' - technica naturalis - he continues to understand the natural in terms of the artificial, the living in terms of the manufactured. Indeed, Kant's distinction between the 'mechanism' and the 'technique' of nature is unclear from the outset because the difference between the natural and the artificial is not thoroughly taken into consideration. Although Kant, instead of claiming that animals really are divine artefacts, merely claims that we perceive them as if they are manufactured by a divine agent, he still relies on the language and logic of a creationist understanding of nature in which the difference between the natural and the artificial remains obscured.

The animality of animals cannot be brought to light as long as they are thought of as artefacts (either real or apparent) and this explains why, notwithstanding Kant's effort to exceed a merely mechanistic understanding of animals, the instrumentalisation of them is maintained on a moral level. In order to develop a more genuine and revealing understanding of what animals are (and, subsequently, of their moral significance) we have to reflect on their way of being.

On several occasions, Heidegger reverts to a basic distinction, made by Aristotle in the second book of his Physics, between the natural and the artificial (Aristotle 1980, Heidegger 1967). Here, Aristotle contends that, whereas some things are manufactured by man, others exist (or come into existence) by nature (1980, 192 b). They have within themselves a principle of movement or change. All natural things change or grow towards their natural final state or goal, but in the case of manufactured things, none of them has within itself the principle of its own making. Rather, it resides in some external agent. Anything that has in itself such a principle, may be said to possess a nature of its own inherently. From an Aristotelian point of view, therefore, the idea of a technica naturalis is obscure because it blurs the basic difference between things that are made (in a technical manner) and things that emerge by themselves (in a natural manner). Although Kant stresses that animals are only perceived as works of art, his language nevertheless continues to rely on the creationist view that had obliterated the Aristotelian distinction between making and emerging.

Moreover, Heidegger (1983) points out that not only the term technica, but also the term organism is inappropriate when it comes to acknowledging the animality of animals because it is derived from organon - which means instrument or equipment. The animal is neither an artefact nor an instrument, nor are the animal's organs instruments put to use by him. Rather, they intrinsically belong to him, animals generate their own organs, generate themselves, move, change and recover all by themselves. Heidegger stresses that to live is not a characteristic of living beings, but rather their basic way of being. Furthermore, the question regarding the animal's way of being cannot be posed (let alone 
answered) by biology or any other science, since it is a philosophical one. Most notably, biology fails to discern the fundamental difference between humans and animals. This difference does not reside in empirical characteristics, such as man's superior intelligence or the absence of fur. Man is not an extremely intelligent animal, he is not an animal, he is not an entity which, besides being an animal, somehow 'has' the ability to think. The difference between man and animal resides in their way of being in the world.

What does Heidegger tell us about the animal's way of being? Whereas a nonorganic entity - such as a stone, for example - does not have a world at all, Heidegger (1983) argues that animals do have a world. Yet, they seem to dwell in a rather poor and restricted one compared to ours. Animals, so it seems, do not really ex-ist, they do not really stand out towards other things, nor towards other possibilities of being and relating. A cow, for example, will notice the grass, but the beauty of the meadow escapes her. The animal hears the sound and tone of a voice, but does not understand the meaning of the word. He is able to bellow, neigh or bray, but will never utter something like a language, he will never really understand or convey meaning (cf. Aristotle 1967, 1253 a 3). Whereas humans are basically responsive and react out of an understanding of what is perceived by them, animals are basically impulsive. Moreover, the possibility of truly becoming involved with things is denied to them - the grass will always remain grass to them and the prey a prey, it will never become something funny or lovely, charming or beautiful, let alone pitiful. An object which cannot be somehow connected with the animal's vital interests and needs, is not perceived at all and remains insignificant to him. Moreover, his world will never change. The human being, however, stands out to and builds his world, uncovering aspects of the world which to animals remain forever hidden. In order to understand what animals really are, therefore, we must acknowledge that they are neither divine artefacts, nor machines, nor human beings. They inhabit a world forever incomparable with ours. An impoverished world - at least from a human point of view.

In his book on Nietzsche, Heidegger (1961) puts forward a similar point of view. The animal does not know what it wants, one cannot even say that it really wants something (p. 66), for it is merely urged or driven by impulse. To will something involves an understanding of what is desired. Hunger, for example, urges the animal to feed himself, but according to Heidegger we cannot say that the animal has a representation of food as such. His appetites are deprived of understanding (i.e. the ability to understand something as something). Elsewhere, however, Heidegger acknowledges that the animal produces a particular interpretation of the world, albeit a rather limited one (p. 243). The environment is interpreted from a certain perspective, namely in terms of possibilities for absorbing things, in terms of possibilities for life-enhancement. The animal only perceives what can be absorbed or used in order to enhance life. All things which cannot be interpreted in such terms, or which do not allow the animal to further its existence, will simply not be perceived at all. 


\section{HUB ZWART}

In short, whenever Heidegger speaks of animals, his language seems to convey a sense of restriction, poverty, deficiency and closure. Only humans are granted the possibility of being susceptible in a genuine sense to what surrounds them; they build a world, rather than respond to an environment composed of a rather limited set of objects. Compared to ours, the animal's world seems profoundly obscure. They will never experience anything like the sudden uplift which may at times occur when we are, for example, reading poetry or involved in an intimate conversation. Although it cannot be excluded that animals dwell in an openness of their own, we cannot know or say anything about it.

Although elsewhere Heidegger often relies on the possibilities of poetry for surpassing and leaping beyond seemingly inescapable but unsatisfactory forms of understanding, Blans (1996) emphasises that this is not the case where animals are concerned. I fact, in one of his elegies, the Poet Rilke assigns an openness to animals which surpasses our objectivistic way of perceiving things, and he adds that, through the mysterious gaze of animals, we ourselves might regain a susceptibility now lost to us. This possibility for interpreting the animal's gaze is bluntly rejected by Heidegger and castigated as being the expression of a popular and biologistic kind of metaphysics which prefers animal impulse to human understanding.

According to Oudemans (1996), however, on further reflection Heidegger's understanding of animals contains another, less disappointing possibility. To begin with, he argues, it is not Heidegger's intention to draw a comparison between humans and animals. Rather, it is while speaking about 'world' that the animal's way of being is addressed. Primarily, Heidegger is interested in human existence. To stand out towards the world means to experience it as something completely astonishing to us. And it is here that the animal presents itself to us and reveals its mysterious gaze, which calls for wonderment rather than disdain. For apparently, they have their own way of standing out towards the world, one we cannot enter. We cannot really image what their world looks like without reverting to anthropomorphism, or to a mere biologistic understanding. And this is our poverty. The possibility of existence open to animals is forever denied to us. It may well be that animals have their own way of standing out to things, of becoming involved with things, and perhaps their world merely seems poor because it is obscure to $u s$, because it is a world into which we will never really be able to follow them. Due to their mysterious gaze, Oudemans claims, animals allow us in an unfathomable way to turn away from our own susceptibility to the world and become, to a limited extent, involved in theirs. Heidegger's contention regarding the poverty of animals should therefore not be interpreted in terms of deprivation, with the implication that our way of standing out towards the world should be regarded as a standard compared to which all other forms of life must be regarded as deficient, because we cannot really know what the animal's world looks like. To a certain extent we can immerse into their world, but the possibility of really following them into it is denied to us. The enigmatic aspect of animal 
WHAT IS AN ANIMAL?

existence, their unfathomable way of standing out to things calls for wonderment and awe; and Oudemans refers to a beautiful passage where it is suggested that the floating, singing and calling of a bird in the summer sky calls us and brings us into the open (Heidegger 1979, p. 95). Both man and animal stand out to the world as openness, but each in a way which is inaccessible to the other. I guess this is what Wittgenstein is pointing at when, in his Philosophical Investigations, he claims that, should a lion be able to speak to us, we would not be able to understand him - would not really be able to follow him into his world (1984). ${ }^{5}$ In short, although Heidegger initially seems to adhere to a rather traditional understanding of animals in terms of deprivation, lack of understanding and true involvement, his reflection on the animal's way of being finally seems to point to much more promising possibilities. We now have to ask ourselves whether the basic recognition of the possibility that the animal has his own unfathomable way of standing out towards the world, enables us to develop a moral relationship with them.

\section{POSSIBILITIES FOR A MORAL RELATIONSHIP WITH ANIMALS}

Philosophical detours such as the one undertaken in the previous sections are indispensable if we want our moral assessment of animals to be something more than an arbitrary statement concerning their moral value - statements we can adhere to or reject at will, depending on the interest or sentiments we happen to cherish. In June 1995, for example, a bill on research with animals was put forward in the Dutch Parliament. One of the amendments passed on that occasion demanded that the intrinsic value of animals be respected. Such an utterance must be regarded as highly problematic, for several reasons. Taken in its stronger sense the concept of 'intrinsic value' obscures the extent to which our relationships with humans will always differ from our relationships with animals. It suggests that we should treat animals in a way comparable to how we treat one another, that we should refrain from using or expending them in an instrumental manner and respect them as partners instead. Our actual treatment of animals will always remain at odds with such a demand. But even in its weaker sense it presupposes the idea that the world is composed of facts to which human beings can add something called 'values'. The animal world is interpreted as basically similar to our own, and due to the conceptual confusions which arise from this, we fail to conceptualise the extent to which, during recent decades, and in spite of the apparent increase of our sensibility when it comes to animals, our actual exploitation of them has intensified considerably.

Since time immemorial we have been treating animals not as ends-inthemselves, not as entities of intrinsic value, but in an instrumental way. We cannot ask them to consent to what is being done to them. They either remain indifferent, or offer resistance, and we train and domesticate them in order to 


\section{HUB ZWART}

subdue their basic No (although we are never able to silence it completely). Allow me to elaborate this aspect by means of a quotation borrowed from ancient tragedy. The basic truth conveyed by the famous chorus in Sophocles' Antigone concerning the terrible - deinon - being called man is, that we relate to nature and animals in a basically violent way (Sophocles 1962). Heidegger (1987) rightly emphasises that, rather than containing a moralistic critique of human behaviour, the chorus recognises what we are in a very fundamental way - we cannot refrain from bullying bulls (or other animals), we cannot do otherwise. Does Sophocles' judgement still apply?

Surely it is no coincidence that the current rhetoric about 'intrinsic value', 'animal rights' and animals as 'partners' emerges at a time when animals are actually being subjected to violent practices such as animal research or genetic modification on an unprecedented scale and with an unprecedented intensity. 'Violent' not in the sense that pain is being inflicted, but in the sense that their way of being-in-the-world is neglected or violated. The present discourse on intrinsic value, rights and partnership dates from the period of the Enlightenment and is borrowed from the moral discourse on man. When applied to animals it runs the risk of becoming an ideological veil, concealing the true nature of the profound changes that are actually occurring in our relationship with them. Rather than respecting them for what they really are, we seem to have lost all interest in them and all acquaintance with them. While failing to acknowledge (on a conceptual level) how they differ from us, we are expending them as raw material for our agricultural and scientific industries on a practical level. And although apparently the Dutch amendment urges us to regard animals as moral subjects, it actually is a display of our power to define animals at will, without having to devote ourselves to a serious effort to get to know them or to articulate moral categories that might more genuinely respond to what they are (or to the way we interact with them).

Instead of claiming that, besides being biological entities, to be studied from a biological perspective, animals are endowed with something like 'intrinsic value', to be studied from an ethical perspective, it is the task of a philosopher to analyse the profound changes that have actually occurred in our relationship with animals - changes which can be brought to light if we view them against the backdrop of the history of our relationship with them. Sophocles emphasises our ancestors' abilities to trap and tame animals and to break their resistance. ${ }^{6}$ That is, he stresses our negative power over them. In view of this account, the contemporary discourse on (and actual treatment of) animals indicates that our power has become positive rather than negative, productive rather than repressive. Indeed, for centuries we have been mistreating, exterminating and disregarding them, but quite recently something astonishing has happened: a different, unprecedented power relationship has managed to establish itself. Our ability to mould them, to modify them, to transform them in accordance with our interests, images and needs has increased dramatically. In the days of Sophocles, 
WHAT IS AN ANIMAL?

due to our audacity, intelligence and skill, humans had already acquired a considerable ability to tone down the animal's stubbornness, to force the horse into our halter, the bull under our yoke, the bird into our cage. Indeed, since time immemorial, our ancestors have been domesticating animal by means of selective breeding, denying obstinate individuals a chance to reproduce themselves. But on entering a university laboratory, or a farm where intensive breeding is being practiced, we sense that something has changed. Rather than mistreating the animals, a whole series of efforts is made to secure and monitor their well-being. Instead of exterminating them and depriving them of their natural abilities, university laboratories are producing new characteristics at an astonishingly high pace. Animal welfare has become an intrinsic objective of the power excercised by us and there seems to be no limit to what we allow these animals to become. Our power has become productive, rather than repressive. Rather than restricting them, we are producing new patterns of behaviour.

We must refrain of course from opposing the past to the present in a schematic manner, for ancient power had its positive aspects as well, and certain forms of genetic modification, such as the 'knock down' experiments to which laboratory animals are nowadays subjected, can be regarded as 'negative' techniques. But it cannot be denied that animals suddenly seem to have lost what still remained of their independence, their stubbornness. We are increasingly surrounding ourselves with artificially produced animals, depriving ourselves of the possibility of really meeting them, of really being struck by their unfathomable gaze. I do not demand that this development be nullified or counteracted, for it is not something we 'choose' to do. Rather, it is an event whose basic tendency must be regarded as inevitable. We can point to its positive and negative, its revealing and obscuring (or violating) aspects, but this does not mean that we may pronounce a general moral verdict. Instead of accompanying this development with a persistent moralistic Jeremiad, the philosopher should rather try to understand what is happening, to articulate on a conceptual level what has already occurred in practice.

Moreover, our description of the recent development so far may have been rather biased in the sense that certain possibilities of relating to animals for which this development still allows, have been underestimated and neglected. No doubt, a moral assessment of our relationship with animals must start from our actual estrangement from them. Besides modifying them, we will continue to use them against their will, and we will continue to defend ourselves against them. Moreover, we will do so in an increasingly efficient, scientific and technological manner. This should not incite us, however, to glorify retrospectively an idyllic past which has never existed. Rather, it should trigger the awareness that, even within the technological structures of our present world, other forms of relationship with animals might still be possible. Faced with the traces of their unfathomable possibility of standing out to the world in a way incompatible with ours, we might yet (in the folds and margins of our present world) develop a 


\section{HUB ZWART}

moral response of wonderment and awe, might yet be encouraged to seek genuine forms of companionship, and to enter into a more gentle relationship with them. By doing so, we will allow them to present themselves to us in a manner quite different from the way they are represented by the recently established discourses and practices referred to above. Although Sophocles' chorus contains a profound truth, it does not contain the whole story, nor does it exhaust our behavioural possibilities. Basic forms of acquaintance and companionship with animals, of which Sissy's relationship with horses might stand as an example, will allow us to reconsider our own way of standing out towards the world, will allow the animal to appear in a different light, not as a resource to be spent in the service of human well-being, but a living being commanding our astonishment, simply because it is there and we did not manufacture it.

Tacitus tells us that ancient Germanic tribes kept bands of horses in sacred forests, where priests observed their neighing and snorting. They were regarded as confidants of the gods and on no other revelation was more reliance placed. On special occasions, priests, kings and chiefs of state accompanied them (1958, p. 279). Apparently, these ancients pagans discerned that the sacred horses were dwelling in an openness denied to humans, a clearing which somehow surpassed their own way of standing out. They carefully observed these mysterious beings who were apparently granted an intimacy with forces transcending the restricted boundaries of the human world. By observing them and accompanying them on holy days, they allowed themselves to exceed their restricted way of being, allowed themselves to shed a glance into possibilities of being with which these animals seemed to be intimately acquainted.

Many centuries later, Lemuel Gulliver was left behind by pirates on the shore of an unknown land belonging to the Houyhnhnms, a nobel and generous race of horses, surpassing human beings in their way of standing out to the world in all respects. Gulliver's first encounter with this remarkable species is described as follows: 'The horse started a little when he came near me, but soon recovering himself, looked full in my face with manifest tokens of wonder... I would have pursued my journey, but he placed himself directly in the way, yet looking with a very mild aspect, never offering the least violence. We stood gazing at each other for some time...' (Swift 1967, p. 270/271). Subsequently, after another horse has joined them, the two Houyhnhnms start neighing to one another, using various gestures: 'not unlike those of a philosopher, when he would attempt to solve some new and difficult phenomenon' (p. 272). Swift's intriguing novel is a comic echo, a satirical articulation of the basic sense that there is something to animals like horses which prevents us - both on a conceptual and on a practical level-from describing their way of being merely in terms of deficiency and lack. Rather, by reflecting on what they are, we might further our understanding on what we are ourselves, for the Houyhnhnms' gaze of wonder conveys the possibility of a different way of looking at other species that Grandgrind's restricted mode of perception. 
WHAT IS AN ANIMAL?

Since the days of Lemuel Gulliver, the human world has changed dramatically and irreversibly. In the present situation, virtually all our relationships with animals are preconditioned by technology, one way or the other. Still, the possibility of a true companionship with animals, the possibility of gazing at them in wonderment, will not be completely denied to us. We may still occasionally meet an animal we did not produce, or introduce, or modify ourselves, and we may even meet otherness in animals of our own breeding. The experience of such an encounter, much rather than the disclosure of biological facts about them, will provide a viable starting point for a moral assessment of animals.

\section{NOTES}

Hub A.E. Zwart Ph. D. (1960), philosopher and psychologist, is director of the Center for Ethics, Catholic University of Nijmegen, The Netherlands (CEKUN). In 1993, he published his thesis on consensus formation and pluralism. Besides that, he published several books and articles on philosophical, ethical and bioethical issues. His principal topic of research is the moral significance of nature. He is editor in chief of the Dutch Journal for Medicine and Ethics. Recently he published Ethical consensus and the truth of laughter: the structure of moral transformations (Kampen: Kok Pharos). Address: CEKUN p.o. box 9103, 6500HD Nijmegen, The Netherlands. Telephone: 31.24.3611995; Fax: 31.24.3615564. E-mail: hzwart@PHIL.KUN.NL

${ }^{1}$ Foltz also points to the danger that, in our effort to determine the relationship between human and nonhuman kinds of life, we may overestimate the continuity, either by regarding human beings as merely one sort of animal among others, or by anthropomorphising nonhuman life (1995 p. 131).

2 'Was die Tiere betrifft, so hat zuerst Descartes, mit verehrungswürdiger Kühnheit, den Gedanken gewagt, das Tier als machina zu verstehn: unsre ganze Physiologie bemüht sich um den Beweis dieses Stazes' (Nietzsche, 1980, § 14).

${ }^{3}$ ' $[\mathrm{W}]$ eil Tiere nu als Mittel da sind, indem sie ihrer selbst nicht bewust sind, der Mensch aber des Zweck ist, wo ich nicht mehr fragen kann: "Warum ist der Mensch da?", welches bei den Tieren geschehen kann, so haben wir gegen die Tiere unmittelbar keine Pflichten, zondern die Pflichten gegen die Tiere sind indirekt Pflichten gegen die Menschheit' (1990, p. 256).

4 'Wenn also Anatomici lebendige Tiere zu den Experimenten nehmen, so ist es grausam, ob es gleich zu etwas Gutem gewandt wird. Weil nun die Tiere als Instrumente des Menschen betrachtet werden, so gehts an...' (p. 257).

5 'Wenn eine Löwe sprechen könnte, wir könnten ihn nicht verstehen' (p. 568).

6 'The light-witted birds of the air, the beasts of the weald and the wood

He traps with his woven snare, and the brood of the briny flood.

Master of cunning he: the savage bull, and the hart

Who roams the mountain free, are tamed by his infinite art;

And the shaggy rough-maned steed is broken to bear the bit'

(Sophocles 1962, p. 340; 341-352). 


\section{HUB ZWART}

\section{REFERENCES}

Aquinas, Thomas 1922. Summa Theologica. Taurini: Marietti.

Aristotle 1980. The Physics, Vol. I [The Loeb classical library]. London: Heinemann; Cambridge, Massachusetts: Harvard University Press.

Aristotle 1967. Politics [The Loeb classical library]. London: Heinemann.

Bergson, H. 1940/1969. Le rire. Essai sur la signification du comique. Paris: PUF.

Blans, B. 1996. 'Heidegger over de omgeving van dier en mens'. In B. Blans and S. Lijmbach (eds) Heidegger en de wereld van het dier. Assen: Van Gorcum.

Dickens, C. 1974. Hard Times; for These Times. Oxford: Oxford University Press.

Diogenes Laertius 1925/1979. Lives of eminent philosophers, Vol. 2 (Book 6-10) [Loeb ed.]. Cambridge: Harvard University Press, London: Heinemann.

Foltz, B. 1995. Inhabiting the earth. Heidegger, environmental ethics and the metaphysics of nature. New Jersey: Humanities Press.

Heidegger, M. 1961. Nietzsche 1. Pfüllingen: Neske

Heidegger, M. 1967. 'Vom Wesen und Begriff der Physis. Aristoteles' Physik B, 1'. In: Wegmarken. Frankfurt am Main: Klostermann.

Heidegger, M. 1979. 'Heraklit'. In: Gesamtausgabe 55, Frankfurt am Main: Vittorio Klostermann.

Heidegger, M. 1983. Die Grundbegriffe der Metaphysik. Welt-Endlichkeit-Einsamkeit. Gesamtausgabe, II. Abteilung: Vorlesungen 1923-1944. Band 29/30. Frankfurt am Main: Klosterman.

Heidegger, M. 1987. Einführung in die Metaphysik. Tübingen: Niemeyer.

Kant, I. 1959. Der Streit der Fakultäten. Hamburg: Meiner.

Kant, I. 1990. Eine Vorlesung über Ethik (G. Gerhardt, Hrsg.). Frankfurt am Main: Fischer.

Lacan, J. 1978. Le séminaire 2: Le moi dans la théorie de Freud et dans la technique de la psychanalyse. Paris: Seuil.

Lindeboom, G. 1979. Descartes and medicine. Amsterdam: Rodopi.

Naragon, S. 1990. 'Kant on Descartes and the brutes', Kant Studien, 81: 1-23.

Nietzsche, F. 1980. 'Der Antichrist'. In: G. Colli, M. Montinari (eds) Sämtliche Werke. München/Berlin: DTV/De Gruyter.

Oudemans, W. 1996. 'Arend en slang: de aanblik van en dierenpaar'. In: B. Blans, S. Lijmbach (eds) Heidegger en de wereld van het dier. Assen: Van Gorcum.

Sophocles 1962. 'Antigone'. In: Sophocles 1 (Loeb Edition). London: Heinemann/ Cambridge: Harvard University Press, pp. 309-419.

Swift, J. 1726/1967. Gulliver's Travels. Harmondsworth: Penguin.

Tacitus 1959. Dialogus, Agricola, Germania. London: Heinemann/Cambridge: Harvard University Press.

Wittgenstein, L. 1984. 'Philosophische Untersuchungen'. In: Werkausgabe 1. Frankfurt am Main: Suhrkamp. 